\title{
Hydrotalea sandarakina sp. nov., isolated from a hot spring runoff, and emended descriptions of the genus Hydrotalea and the species Hydrotalea flava
}

Correspondence Milton S. da Costa milton@ci.uc.pt

\author{
Luciana Albuquerque, ${ }^{1}$ Fred A. Rainey, ${ }^{2}$ M. Fernanda Nobre ${ }^{3}$ \\ and Milton S. da Costa ${ }^{3,4}$
}

\author{
${ }^{1}$ Center for Neuroscience and Cell Biology, University of Coimbra, 3004-517 Coimbra, Portugal \\ ${ }^{2}$ Department of Biological Sciences, Louisiana State University, Baton Rouge, LA 70803, USA \\ ${ }^{3}$ Department of Life Sciences, University of Coimbra, 3001-401 Coimbra, Portugal \\ ${ }^{4}$ Microbiology Unit, BIOCANT Biotechnological Park, 3060-197 Cantanhede, Portugal
}

\begin{abstract}
Two bacterial isolates, designated $\mathrm{AF}-51^{\top}$ and $\mathrm{AF}-50$, with an optimum growth temperature of about $45{ }^{\circ} \mathrm{C}$ and an optimum $\mathrm{pH}$ for growth between 6.0 and 6.5, were recovered from a hot spring in the Furnas, Area da Fonte 1825, on the Island of São Miguel in the Azores. Based on 16S rRNA gene sequence analysis, these strains were related most closely to the type strain of Hydrotalea flava at a pairwise similarity of $95.7 \%$. The two strains were orange-pigmented and formed non-motile, rod-shaped cells that stained Gram-negative and were aerobic and oxidaseand catalase-positive. The major fatty acids were iso $-\mathrm{C}_{15: 0}$, iso- $\mathrm{C}_{17: 0} 3-\mathrm{OH}$ and iso- $\mathrm{C}_{16: 0}$. The major respiratory quinone was menaquinone 7 . Based on phylogenetic, physiological and biochemical characteristics, these strains from the Azores are considered to represent a single novel species of the genus Hydrotalea, for which the name Hydrotalea sandarakina sp. nov. is proposed. The type strain is AF- $51^{\top}$ (=DSM $\left.23241^{\top}=\mathrm{LMG} 25526^{\top}\right)$. We provide emended descriptions of the genus $H y d r o t a l e a$ and of $H$. flava to reflect new results obtained in this study.
\end{abstract}

The phylum Bacteroidetes comprises very few known thermophilic or slightly thermophilic organisms. Some of these organisms have slightly elevated growth temperatures in the range $40-45{ }^{\circ} \mathrm{C}$, namely Pseudozobellia thermophila (Nedashkovskaya et al., 2009) and Lutaonella thermophila (Arun et al., 2009), or are slightly thermophilic, such as Anaerophaga thermohalophila (Denger et al., 2002) and Schleiferia thermophila (Albuquerque et al., 2011), with optimum growth temperatures around $50{ }^{\circ} \mathrm{C}$. Thermonema lapsum, Thermonema rossianum and two species of the genus Rhodothermus, Rhodothermus marinus and Rhodothermus profundi, are genuine thermophiles with optimum growth temperatures around $60{ }^{\circ} \mathrm{C}$ or higher (Alfredsson et al., 1987; Hudson et al., 1989; Marteinsson et al., 2010; Nunes et al., 1995; Silva et al., 2000; Tenreiro et al., 1997).

We recently isolated several slightly thermophilic organisms from the Furnas area on the Island of São Miguel in the Azores, such as S. thermophila (Albuquerque et al., 2011), Meiothermus granaticius (Albuquerque et al., 2010), Elioraea tepidiphila (Albuquerque et al., 2008),

The GenBank/EMBL/DDBJ accession number for the $16 \mathrm{~S}$ rRNA gene sequence of strain AF- $51^{\top}$ is JF739858.

A supplementary figure is available with the online version of this paper.
Tepidicella xavieri (França et al., 2006), Truepera radiovictrix (Albuquerque et al., 2005) and Meiothermus timidus (Pires et al., 2005). We also isolated two additional strains $\left(\mathrm{AF}-51^{\mathrm{T}}\right.$ and $\left.\mathrm{AF}-50\right)$ with an optimum growth temperature around $45{ }^{\circ} \mathrm{C}$ and a maximum growth temperature of $52.5{ }^{\circ} \mathrm{C}$ from this area, which are closely related to the recently described Hydrotalea flava, which has an optimum growth temperature around $30{ }^{\circ} \mathrm{C}$ (Kämpfer et al., 2011). Based on phylogenetic, physiological and biochemical parameters, we consider that these two strains represent a single novel species of the genus Hydrotalea.

Strains $\mathrm{AF}-51^{\mathrm{T}}$ and AF-50 were isolated from a hot spring of the Furnas area, known as Área da Fonte 1825. Water samples were maintained without temperature control for 6 days, and 10-100 $\mathrm{ml}$ was then filtered through membrane filters (Gelman type GN-6; pore size $0.45 \mu \mathrm{m}$, diameter $47 \mathrm{~mm}$ ). The filters were placed on the surface of solidified Thermus medium (Williams \& da Costa, 1992), the plates were wrapped in plastic to prevent evaporation and incubated at $50{ }^{\circ} \mathrm{C}$ for up to 4 days. Cultures were purified by subculturing and the isolates were stored at $-70{ }^{\circ} \mathrm{C}$ in Thermus medium with $15 \%$ (w/v) glycerol. H. flava CCUG $51397^{\mathrm{T}}$ and Escherichia coli DSM $30083^{\mathrm{T}}$ were used for comparative purposes. 
Unless stated otherwise, all biochemical and tolerance tests were performed as described previously (Albuquerque et al., 2011; Smibert \& Krieg, 1981), in Thermus medium or on Thermus agar (Williams \& da Costa, 1992) at $45{ }^{\circ} \mathrm{C}$ for up 6 days. Cell morphology and motility were examined by phase-contrast microscopy during the exponential-growth phase. The presence of flexirubin-type pigments was determined by flooding a small mass of bacterial cells with $20 \% \mathrm{KOH}$ according to Bernardet et al. (2002). The growth temperature range of the strains was examined between 20 and $55{ }^{\circ} \mathrm{C}\left(5{ }^{\circ} \mathrm{C}\right.$ increments) by measuring the turbidity $(610 \mathrm{~nm})$ of cultures incubated in $300 \mathrm{ml}$ metal-capped Erlenmeyer flasks, containing $100 \mathrm{ml}$ medium in a rotary water-bath shaker at 150 r.p.m. The $\mathrm{pH}$ range for growth was examined in liquid medium by using $50 \mathrm{mM}$ citratephosphate buffer, MES, HEPES, TAPS and CAPSO over a $\mathrm{pH}$ range from 4.0 to 9.0 in a rotary water-bath shaker. The salt tolerance of the organisms was determined in liquid medium, with $\mathrm{NaCl}$ ranging between 0.0 and $2.0 \%$. Catalase, oxidase and DNase activities were examined as described previously (Albuquerque et al., 2011; Smibert \& Krieg, 1981). Additional enzyme activities were determined by using the API ZYM system (bioMérieux) at $45^{\circ} \mathrm{C}$. Anaerobic growth was assessed in cultures in the same medium, containing $\mathrm{KNO}_{3}\left(1.0 \mathrm{~g} \mathrm{l}^{-1}\right)$, incubated in anaerobic chambers (GENbox anaer; bioMérieux). Single carbon source assimilation tests were performed in a medium composed of Thermus basal salts (Williams \& da Costa, 1992) to which filter-sterilized ammonium sulfate $\left(0.5 \mathrm{~g} \mathrm{l}^{-1}\right)$, yeast extract $\left(0.2 \mathrm{~g} \mathrm{l}^{-1}\right)$ and the carbon source $\left(2.0 \mathrm{~g} \mathrm{l}^{-1}\right)$ were added. Growth of the strains on single carbon sources was examined by measuring the turbidity of cultures incubated at $45{ }^{\circ} \mathrm{C}$ in $20 \mathrm{ml}$ screw-capped tubes containing $10 \mathrm{ml}$ of medium for up to 6 days. Acid production from carbohydrates was determined by using the API $50 \mathrm{CH}$ system (bioMérieux) according to the manufacturer's instructions, with API $50 \mathrm{CHB} / \mathrm{E}$ medium. Results were recorded after $48 \mathrm{~h}$ and 6 days incubation at $45{ }^{\circ} \mathrm{C}$.
Cultures for polar lipid analysis of $H$. flava CCUG $51397^{\mathrm{T}}$ and strains AF-51 ${ }^{\mathrm{T}}$ and AF-50 were grown in 11 Erlenmeyer flasks containing $250 \mathrm{ml}$ medium at the optimum growth temperature in a rotary water-bath shaker until the late-exponential phase of growth. Harvesting of the cultures and extraction of lipids were performed as described previously (da Costa et al., 2006). Individual polar lipids were separated by two-dimensional TLC and visualized as described previously (da Costa et al., 2006). Lipoquinones were extracted from freeze-dried cells and purified by TLC as described previously (da Costa et al., 2006). The lipoquinones were separated by HPLC with a Gilson HPLC system by using a reversed-phase Hichrom 5 C18 column and methanol/heptane $(10: 2, \mathrm{v} / \mathrm{v})$ as the mobile phase and were detected at $269 \mathrm{~nm}$. Cultures for fatty acid analysis were grown on solidified R2A medium (Reasoner \& Geldreich, 1985), in sealed plastic bags submerged in a water bath at 28 and $45^{\circ} \mathrm{C}$ for $24 \mathrm{~h}$. Fatty acid methyl esters were obtained from fresh wet biomass and separated, identified and quantified with the standard MIS Library Generation Software (Microbial ID) as described previously (da Costa et al., 2006).

DNA for determination of the $\mathrm{G}+\mathrm{C}$ content was isolated as described by Nielsen et al. (1995). The G $+C$ content of the DNA was determined by HPLC as described by Mesbah et al. (1989).

16S rRNA gene sequences were determined as described previously (Rainey et al., 1996). A phylogenetic dendrogram (Fig. 1) showing the relationships between strain AF- $51^{\mathrm{T}}$ and related taxa was constructed by the neighbour-joining method with the MEGA 4.0 software package (Tamura et al., 2007). Comparative analysis of the 16S rRNA gene sequences of strains AF- $51^{\mathrm{T}}$ and AF- 50 showed that they were affiliated with taxa of the family Chitinophagaceae, order Sphingobacteriales, phylum Bacteroidetes. The sequences of the two strains shared $100 \%$ pairwise similarity and showed highest similarity to the type strains of Hydrotalea flava

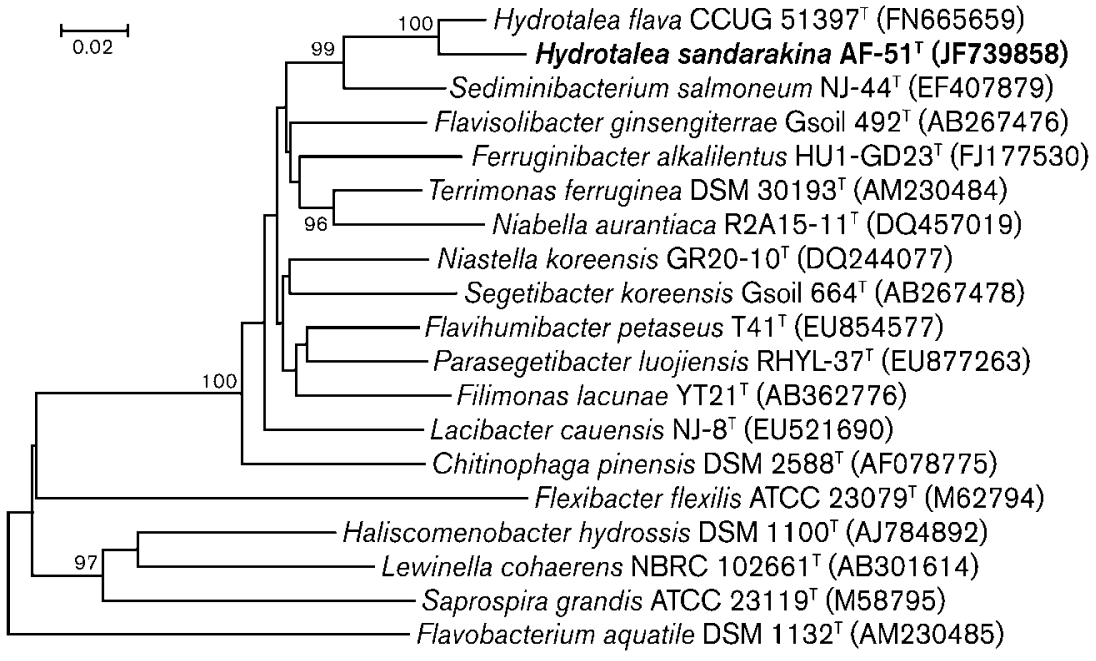

Fig. 1. Neighbour-joining phylogenetic dendrogram based on $16 \mathrm{~S}$ rRNA gene sequences showing the relationship between strain $A F-51^{\top}$ and related taxa of the family Chitinophagaceae. Bootstrap values percentages of 1000 replications) are shown at branch points. Bar, 2 inferred changes per $100 \mathrm{nt}$. 
(95.7\%) (Kämpfer et al., 2011) and Sediminibacterium salmoneum (91.7\%) (Qu \& Yuan, 2008).

Strains $\mathrm{AF}-51^{\mathrm{T}}$ and AF-50 formed short, Gram-negative, rod-shaped cells $(0.3-0.5 \mu \mathrm{m}$ wide and $1.0-3.0 \mu \mathrm{m}$ long) that lacked flagella. Colonies were orange-pigmented on Thermus medium, but flexirubin-type pigments were not detected. The organisms had an optimum growth temperature of about $45{ }^{\circ} \mathrm{C}$ but did not grow at 20 or $55{ }^{\circ} \mathrm{C}$, in contrast to the type strain of $H$. flava, which has a growth temperature range of $20-37{ }^{\circ} \mathrm{C}$ and an optimum growth temperature of $25-30{ }^{\circ} \mathrm{C}$ (Table 1). The strains were oxidase- and catalase-positive and hydrolysed hippurate, aesculin, arbutin, starch, gelatin and casein. Xylan was not hydrolysed. Other enzyme activities are listed in the species description below. A small amount of yeast extract $\left(0.2 \mathrm{~g} \mathrm{l}^{-1}\right)$ was added to the minimal medium to assess assimilation of single carbon sources. Strains $A F-51^{\mathrm{T}}$ and AF-50 produced acid from several carbohydrates. Nitrate was not reduced to nitrite. Anaerobic growth with nitrate as electron acceptor was not observed.

The polar lipid pattern on thin-layer chromatograms revealed the presence of phosphatidylethanolamine, two aminophospholipids, two aminolipids and four unidentified lipids with migration identical to those of the type strain of H. flava (Fig. S1 in IJSEM Online). The major respiratory lipoquinone was menaquinone 7 , as in all members of the family Chitinophagaceae examined. The fatty acid profile of strains $\mathrm{AF}-51^{\mathrm{T}}$ and $\mathrm{AF}-50$ was dominated by iso- $\mathrm{C}_{15: 0}$, iso- $\mathrm{C}_{17: 0} 3-\mathrm{OH}$ and iso- $\mathrm{C}_{16: 0}$ (Table 2). The type strain of $H$. flava as well as strains $\mathrm{AF}-51^{\mathrm{T}}$ and AF-50 possessed similar fatty acids, but there were noticeable differences in the levels of several components, namely iso- $\mathrm{C}_{17: 0} \quad 3-\mathrm{OH}$ and iso- $\mathrm{C}_{16: 0}$, among the strains when grown at $28{ }^{\circ} \mathrm{C}$. The $\mathrm{G}+\mathrm{C}$ content of the DNA of strains AF- $51^{\mathrm{T}}$ and AF-50 was $35.2 \pm 0.5$ and $35.3 \pm 0.5 \mathrm{~mol} \%$, respectively (mean $\pm \mathrm{SD}$ of 3 determinations).

We thus propose that strains AF- $51^{\mathrm{T}}$ and AF-50 represent a novel species of the genus Hydrotalea. These strains can be differentiated from the type and only species of the genus Hydrotalea, H. flava, based on both phylogenetic and phenotypic characteristics.

To carry out a full comparative study, we obtained $H$. flava CCUG $51397^{\mathrm{T}}$ from the Culture Collection of the University of Göteborg, Sweden (CCUG). The DNA G+C content of strain $\mathrm{AF}-51^{\mathrm{T}}(35.2 \pm 0.5 \mathrm{~mol} \%$, Table 2) differed from that of $H$. flava CCUG $51397^{\mathrm{T}}$ (42 mol\%, Kämpfer et al., 2011) by approx. $7 \mathrm{~mol} \%$. To confirm this, the DNA G $+\mathrm{C}$ content of $H$. flava CCUG $51397^{\mathrm{T}}$ was determined in the present study, giving a value of $37.0 \pm 0.3 \mathrm{~mol} \%$. This discrepancy may be due to the use of a different method of determination, although the method used in the original paper (Kämpfer et al., 2011) was not specified. We also used genomic DNA of E. coli DSM $30083^{\mathrm{T}}$, which had a G+C content of $50.7 \pm$ $0.6 \mathrm{~mol} \%$, as a control. Comparison of $H$. flava CCUG $51397^{\mathrm{T}}$ and strain $\mathrm{AF}-51^{\mathrm{T}}$ in carbon-source assimilation and acid-production studies revealed some differences between the results that we obtained and those reported by Kämpfer et al. (2011). These differences are indicated in Table 1 and in the emended description of $H$. flava. These differences could result from the use of different basal media and/or the different methods used in the original study of Kämpfer et al. (2011), but with the two strains

Table 1. Differential characteristics between strains AF-51 ${ }^{\top}$ and AF-50 and Hydrotalea flava CCUG $51397^{\top}$

Data are from this study except where indicated otherwise.

\begin{tabular}{|c|c|c|}
\hline Characteristic & Strains AF-51 ${ }^{\mathrm{T}} / \mathrm{AF}-50$ & H. flava CCUG $51397^{\mathrm{T}}$ \\
\hline Pigmentation & Orange & Orange-yellow \\
\hline Growth temperature range $\left({ }^{\circ} \mathrm{C}\right)$ & $25-52.5$ & $20-37^{\star}$ \\
\hline \multicolumn{3}{|l|}{ Assimilation of: } \\
\hline L-Rhamnose & - & + \\
\hline Glycerol & + & - \\
\hline D-Gluconate & + & - \\
\hline Proline & + & - \\
\hline \multicolumn{3}{|l|}{ Acid production from: } \\
\hline D-Ribose & + & - \\
\hline D-Galactose & - & + \\
\hline L-Rhamnose & - & + \\
\hline
\end{tabular}

*Data from Kämpfer et al. (2011). 
Table 2. Fatty acid profiles of strains $A F-51^{\top}$ and $A F-50$ grown at 28 and $45^{\circ} \mathrm{C}$, and of Hydrotalea flava $\mathrm{CCUG} 51397^{\top}$ grown at $28^{\circ} \mathrm{C}$

Results are percentages of the total fatty acids (mean $\pm \mathrm{SD}$ of two to four analyses); tr, trace $(<0.5 \%)$; - , not detected.

\begin{tabular}{|c|c|c|c|c|c|}
\hline \multirow[t]{2}{*}{ Fatty acid ${ }^{*}$} & \multicolumn{2}{|c|}{$A F-51^{T}$} & \multicolumn{2}{|c|}{ AF-50 } & \multirow{2}{*}{$\frac{\text { H. flava CCUG } 51397^{\mathrm{T}}}{28^{\circ} \mathrm{C}}$} \\
\hline & $28^{\circ} \mathrm{C}$ & $45^{\circ} \mathrm{C}$ & $28^{\circ} \mathrm{C}$ & $45^{\circ} \mathrm{C}$ & \\
\hline Unknown ECL 12.560 & $1.6 \pm 0.1$ & $\operatorname{tr}$ & $1.5 \pm 0.1$ & $\operatorname{tr}$ & $1.1 \pm 0.2$ \\
\hline iso- $\mathrm{C}_{13: 0}$ & $2.0 \pm 0.1$ & $2.5 \pm 0.1$ & $2.1 \pm 0.1$ & $2.3 \pm 0.2$ & $3.8 \pm 0.3$ \\
\hline Unknown ECL 13.565 & $4.9 \pm 0.3$ & $2.0 \pm 0.1$ & $4.8 \pm 0.3$ & $1.2 \pm 0.1$ & $3.0 \pm 0.4$ \\
\hline iso- $\mathrm{C}_{14: 0}$ & $1.8 \pm 0.1$ & $2.0 \pm 0.2$ & $1.8 \pm 0.1$ & $1.9 \pm 0.2$ & $0.7 \pm 0.1$ \\
\hline $\mathrm{C}_{14: 0}$ & $\operatorname{tr}$ & $0.7 \pm 0.1$ & $\operatorname{tr}$ & $0.8 \pm 0.2$ & - \\
\hline iso- $\mathrm{C}_{15: 1} \mathrm{G}$ & - & $\operatorname{tr}$ & - & $\operatorname{tr}$ & $2.5 \pm 0.3$ \\
\hline iso- $\mathrm{C}_{15: 0}$ & $26.2 \pm 0.2$ & $41.2 \pm 1.4$ & $27.2 \pm 0.3$ & $42.6 \pm 0.2$ & $24.9 \pm 0.5$ \\
\hline anteiso- $\mathrm{C}_{15: 0}$ & $5.2 \pm 0.1$ & $0.6 \pm 0.1$ & $5.6 \pm 0.1$ & $0.7 \pm 0.1$ & $2.8 \pm 0.3$ \\
\hline $\mathrm{C}_{15: 0}$ & $0.7 \pm 0.1$ & $0.6 \pm 0.1$ & $1.0 \pm 0.1$ & $1.3 \pm 0.3$ & $1.7 \pm 0.2$ \\
\hline iso- $\mathrm{C}_{16: 1} \mathrm{H}$ & $1.7 \pm 0.1$ & - & $1.7 \pm 0.1$ & - & $0.7 \pm 0.1$ \\
\hline iso- $\mathrm{C}_{16: 0}$ & $8.4 \pm 0.4$ & $10.2 \pm 0.5$ & $8.0 \pm 0.2$ & $11.1 \pm 0.3$ & $4.3 \pm 0.4$ \\
\hline Summed feature 3 & $6.9 \pm 0.2$ & $2.6 \pm 0.2$ & $7.1 \pm 0.2$ & $1.8 \pm 0.2$ & $3.2 \pm 0.3$ \\
\hline $\mathrm{C}_{16: 0}$ & $2.4 \pm 0.1$ & $4.4 \pm 0.3$ & $2.3 \pm 0.1$ & $6.4 \pm 0.6$ & $3.1 \pm 0.2$ \\
\hline iso- $\mathrm{C}_{15: 0} 3-\mathrm{OH}$ & $2.8 \pm 0.1$ & $3.8 \pm 0.2$ & $2.8 \pm 0.1$ & $3.0 \pm 0.2$ & $3.8 \pm 0.4$ \\
\hline $\mathrm{C}_{15: 0} 2-\mathrm{OH}$ & $0.6 \pm 0.1$ & - & $0.6 \pm 0.1$ & - & $0.6 \pm 0.1$ \\
\hline Summed feature 9 & $6.6 \pm 0.3$ & $\operatorname{tr}$ & $6.0 \pm 0.2$ & $\operatorname{tr}$ & $3.0 \pm 0.2$ \\
\hline Summed feature 4 & $0.8 \pm 0.2$ & - & $0.8 \pm 0.2$ & - & - \\
\hline Unknown ECL 16.582 & $0.7 \pm 0.1$ & $0.7 \pm 0.1$ & $0.6 \pm 0.1$ & $0.6 \pm 0.1$ & $1.3 \pm 0.2$ \\
\hline iso- $\mathrm{C}_{17: 0}$ & $3.1 \pm 0.2$ & $4.4 \pm 0.2$ & $2.7 \pm 0.2$ & $3.8 \pm 0.2$ & $5.6 \pm 0.4$ \\
\hline $\mathrm{C}_{17: 1} \omega 6 c$ & $1.6 \pm 0.1$ & $1.1 \pm 0.1$ & $1.5 \pm 0.1$ & $0.9 \pm 0.1$ & $\operatorname{tr}$ \\
\hline iso- $\mathrm{C}_{16: 0} 3-\mathrm{OH}$ & $4.2 \pm 0.2$ & $5.5 \pm 0.3$ & $4.3 \pm 0.2$ & $4.4 \pm 0.4$ & $5.3 \pm 0.5$ \\
\hline $\mathrm{C}_{16: 0} 3-\mathrm{OH}$ & $1.5 \pm 0.1$ & $1.7 \pm 0.2$ & $1.5 \pm 0.1$ & $2.1 \pm 0.2$ & $2.5 \pm 0.3$ \\
\hline iso- $\mathrm{C}_{17: 0} 3-\mathrm{OH}$ & $10.5 \pm 0.4$ & $14.2 \pm 0.6$ & $9.8 \pm 0.3$ & $13.5 \pm 0.8$ & $20.9 \pm 1.0$ \\
\hline $\mathrm{C}_{17: 0} 2-\mathrm{OH}$ & $1.3 \pm 0.1$ & $\operatorname{tr}$ & $1.3 \pm 0.1$ & $\operatorname{tr}$ & $1.7 \pm 0.4$ \\
\hline $\mathrm{C}_{17: 0} 3-\mathrm{OH}$ & $\operatorname{tr}$ & - & $\operatorname{tr}$ & - & $0.6 \pm 0.1$ \\
\hline
\end{tabular}

${ }^{*}$ ECL, Equivalent chain-length. Summed features represent groups of two or three fatty acids that could not be separated by GLC with the MIDI System: summed feature 3 comprises $\mathrm{C}_{16: 1} \omega 7 c$ and/or $\mathrm{C}_{16: 1} \omega 6 c$; summed feature 4 comprises iso- $\mathrm{C}_{17: 1}$ I and/or anteiso- $\mathrm{C}_{17: 1} \mathrm{~B}$; summed feature 9 comprises iso- $\mathrm{C}_{17: 1} \omega 9 c$ and/or $\mathrm{C}_{16: 0} 10$-methyl.

compared side by side, the data that we obtained on Thermus basal salts medium still show taxonomically significant differences between the new isolate and $H$. flava. Given the differences that we observed when testing the type strain of $H$. flava in our laboratory and to verify the identity of the strain that we obtained from CCUG, we determined the full 16S rRNA gene sequence of $H$. flava CCUG $51397^{\mathrm{T}}$ and found it to be identical to that deposited in GenBank under accession no. FN665659. The emended descriptions of the genus Hydrotalea and of $H$. flava provided below reflect the additional data obtained in this study. The two novel strains differ from H. flava CCUG $51397^{\mathrm{T}}$ by $>3 \%$ in $16 \mathrm{~S}$ rRNA gene sequence; the optimal temperature for growth differs by 15-20 ${ }^{\circ} \mathrm{C}$; there are also several differences in assimilation of single carbon sources and they can be easily distinguished from $H$. flava based on their fatty acid composition. On the basis of these results, we suggest that strains $\mathrm{AF}-51^{\mathrm{T}}$ and AF-50 represent a single novel species of the genus Hydrotalea, for which we propose the name Hydrotalea sandarakina sp. nov.

\section{Emended description of Hydrotalea Kämpfer et al. 2011}

Characteristics are as given for the description of the genus by Kämpfer et al. (2011) with the following amendments. Some species of the genus are slightly thermophilic. The major fatty acids are iso- $\mathrm{C}_{15: 0}$ and iso- $\mathrm{C}_{17: 0} 3-\mathrm{OH}$.

\section{Emended description of Hydrotalea flava Kämpfer et al. 2011}

Characteristics are as given for the description of the species by Kämpfer et al. (2011) with the following amendments. Grows in media with up to $1 \% \mathrm{NaCl}$. The following carbon sources are assimilated using Thermus basal salts medium: D-glucose, D-fructose, D-galactose, 
D-mannose, L-rhamnose, D-xylose, sucrose, maltose, cellobiose, trehalose, aspartate and L-ornithine; glycerol, sorbitol, DL-lactate, pyruvate, D-gluconate, L-alanine, proline and L-serine are not assimilated. In API ZYM tests, positive for alkaline phosphatase, esterase (C4), esterase lipase (C8), leucine arylamidase, valine arylamidase, cystine arylamidase, trypsin, $\alpha$-chymotrypsin, acid phosphatase, naphthol-AS-BI-phosphohydrolase, $\alpha$-galactosidase, $\beta$-galactosidase, $\beta$-glucuronidase, $\alpha$-glucosidase, $\beta$-glucosidase, $N$-acetyl- $\beta$-glucosaminidase, $\alpha$-mannosidase and $\alpha$ fucosidase, but negative for lipase (C14). Acid is produced from D-xylose, D-galactose, D-glucose, D-fructose, D-mannose, L-rhamnose, methyl $\alpha$-D-mannopyranoside, methyl $\alpha$ D-glucopyranoside, $\mathrm{N}$-acetylglucosamine, amygdalin, arbutin, aesculin ferric citrate, salicin, cellobiose, maltose, lactose, melibiose, sucrose, trehalose, melezitose, raffinose, starch, glycogen, gentiobiose and turanose (API $50 \mathrm{CH}$ ). The DNA $\mathrm{G}+\mathrm{C}$ content of strain CCUG $51397^{\mathrm{T}}$ is $37.0 \pm 0.3 \mathrm{~mol} \%$ (HPLC).

\section{Description of Hydrotalea sandarakina sp. nov.}

Hydrotalea sandarakina (san.da.ra'ki.na. N.L. fem. adj. sandarakina from Gr. fem. adj. sandarakinê of orange colour).

Cells are non-motile rods, $1.0-3.0 \mu \mathrm{m}$ long and 0.3-0.5 $\mu \mathrm{m}$ wide. Gram-stain-negative. Endospores are not formed. Colonies on Thermus medium are orange-pigmented. Aerobic, organotrophic, oxidase- and catalase-positive. Growth occurs at $25-52.5{ }^{\circ} \mathrm{C}$. The optimum growth temperature is about $45^{\circ} \mathrm{C}$; growth does not occur at 20 or $55{ }^{\circ} \mathrm{C}$. The optimum $\mathrm{pH}$ for growth is $6.0-6.5$; growth does not occur at $\mathrm{pH} 4.0$ or 9.0. Optimum growth occurs in the absence of $\mathrm{NaCl}$, but grows in media with up to $1 \%$ $\mathrm{NaCl}$. Yeast extract is required for growth. Nitrate is not reduced to nitrite. Flexirubin-type pigments are absent. The polar lipid profile is composed of phosphatidylethanolamine, two aminophospholipids, two aminolipids and four unidentified lipids; the major fatty acids are iso- $\mathrm{C}_{15: 0}$, iso- $\mathrm{C}_{17: 0} 3-\mathrm{OH}$ and iso- $\mathrm{C}_{16: 0}$. Menaquinone 7 is the major respiratory quinone. Gelatin, casein, starch, aesculin, arbutin and hippurate are degraded but xylan is not. DNase-positive. In API ZYM tests, positive for alkaline phosphatase, esterase (C4), esterase lipase (C8), leucine arylamidase, valine arylamidase, cystine arylamidase, trypsin, $\alpha$-chymotrypsin, acid phosphatase, naphtholAS-BI-phosphohydrolase, $\alpha$-galactosidase, $\beta$-galactosidase, $\beta$-glucuronidase, $\alpha$-glucosidase, $\beta$-glucosidase, $N$-acetyl- $\beta$ glucosaminidase, $\alpha$-mannosidase and $\alpha$-fucosidase, but negative for lipase (C14). Assimilates D-glucose, D-fructose, D-galactose, D-mannose, D-xylose, sucrose, maltose, lactose, cellobiose, trehalose, raffinose, melezitose, glycerol, DLlactate, D-gluconate, D-glucuronate, aspartate, glutamate, proline and L-ornithine, but not L-rhamnose, L-fucose, L-sorbose, D-ribose, D-arabinose, L-arabinose, ribitol, xylitol, sorbitol, mannitol, myo-inositol, erythritol, Darabitol, L-arabitol, $\alpha$-ketoglutarate, acetate, pyruvate, succinate, malate, citrate, benzoate, fumarate, formate, L-alanine, L-aspargine, glycine, L-histidine, L-lysine, Lglutamine, L-arginine, L-serine, valine, L-phenylalanine, Lleucine, L-isoleucine, methionine or threonine. Acid is produced from D-ribose, D-xylose, D-glucose, D-fructose, D-mannose, methyl $\alpha$-D-mannopyranoside, methyl $\alpha$-Dglucopyranoside, $N$-acetylglucosamine, amygdalin, arbutin, aesculin ferric citrate, salicin, cellobiose, maltose, lactose, melibiose, sucrose, trehalose, melezitose, raffinose, starch, glycogen, gentiobiose, turanose and potassium 5-ketogluconate (API $50 \mathrm{CH}$ ). The DNA G $+\mathrm{C}$ content of the type strain is $35.2 \pm 0.5 \mathrm{~mol} \%$ (HPLC).

The type strain, AF- $51^{\mathrm{T}}\left(=\mathrm{DSM} 23241^{\mathrm{T}}=\mathrm{LMG} 25526^{\mathrm{T}}\right)$, was isolated from runoff of the hot spring known as Área da Fonte 1825, Furnas, on the Island of São Miguel in the Azores. AF-50 (=DSM 23242=LMG 25527) is an additional strain of the species.

\section{Acknowledgements}

We are indebted to Professor Jean P. Euzéby (École National Vétérinaire, Toulouse, France) for help with etymology. This research was funded, in part, by Fundação para a Ciência e a Tecnologia (PTDC/BIA-MIC/105247/2008).

\section{References}

Albuquerque, L., Simões, C., Nobre, M. F., Pino, N. M., Battista, J. R., Silva, M. T., Rainey, F. A. \& da Costa, M. S. (2005). Truepera radiovictrix gen. nov., sp. nov., a new radiation resistant species and the proposal of Trueperaceae fam. nov. FEMS Microbiol Lett 247, 161-169.

Albuquerque, L., Rainey, F. A., Nobre, M. F. \& da Costa, M. S. (2008). Elioraea tepidiphila gen. nov., sp. nov., a slightly thermophilic member of the Alphaproteobacteria. Int J Syst Evol Microbiol 58, 773-778.

Albuquerque, L., Rainey, F. A., Nobre, M. F. \& da Costa, M. S. (2010). Meiothermus granaticius sp. nov., a new slightly thermophilic redpigmented species from the Azores. Syst Appl Microbiol 33, 243-246.

Albuquerque, L., Rainey, F. A., Nobre, M. F. \& da Costa, M. S. (2011). Schleiferia thermophila gen. nov., sp. nov., a slightly thermophilic bacteria of the phylum Bacteroidetes and the proposal of Schleiferiaceae fam. nov. Int J Syst Evol Microbiol 61, 2450-2455.

Alfredsson, G. A., Kristjansson, J. K., Hjörleifsdottir, S. H. \& Stetter, K. O. (1987). Rhodothermus marinus, gen. nov., sp. nov., a thermophilic, halophilic bacterium from submarine hot springs in Iceland. J Gen Microbiol 134, 299-306.

Arun, A. B., Chen, W.-M., Lai, W.-A., Chou, J.-H., Shen, F.-T., Rekha, P. D. \& Young, C.-C. (2009). Lutaonella thermophila gen. nov., sp. nov., a moderately thermophilic member of the family Flavobacteriaceae isolated from a coastal hot spring. Int J Syst Evol Microbiol 59, 2069-2073.

Bernardet, J.-F., Nakagawa, Y., Holmes, B. \& Subcommittee on the taxonomy of Flavobacterium and Cytophaga-like bacteria of the International Committee on Systematics of Prokaryotes (2002). Proposed minimal standards for describing new taxa of the family Flavobacteriaceae and emended description of the family. Int J Syst Evol Microbiol 52, 1049-1070.

da Costa, M. S., Nobre, M. F. \& Wait, R. (2006). Analysis of lipids from extremophilic bacteria. In Methods in Microbiology, vol. 35, pp. 127159. Edited by F.A. Rainey \& A. Oren. Amsterdam: Elsevier. 
Denger, K., Warthmann, R., Ludwig, W. \& Schink, B. (2002). Anaerophaga thermohalophila gen. nov., sp. nov., a moderately thermohalophilic, strictly anaerobic fermentative bacterium. Int $J$ Syst Evol Microbiol 52, 173-178.

França, L., Rainey, F. A., Nobre, M. F. \& da Costa, M. S. (2006). Tepidicella xavieri gen. nov., sp. nov., a betaproteobacterium isolated from a hot spring runoff. Int J Syst Evol Microbiol 56, 907-912.

Hudson, J. A., Schofield, K. M., Morgan, H. W. \& Daniel, R. M. (1989). Thermonema lapsum gen. nov., sp. nov., a thermophilic gliding bacterium. Int J Syst Bacteriol 39, 485-487.

Kämpfer, P., Lodders, N. \& Falsen, E. (2011). Hydrotalea flava gen. nov., a new member of the phylum Bacteroidetes and allocation of the genera Chitinophaga, Sediminibacterium, Lacibacter, Flavihumibacter, Flavisolibacter, Niabella, Niastella, Segetibacter, Parasegetibacter, Terrimonas, Ferruginibacter, Filimonas and Hydrotalea to the family Chitinophagaceae fam. nov. Int J Syst Evol Microbiol 61, 518-523.

Marteinsson, V. T., Bjornsdottir, S. H., Bienvenu, N. \& Kristjannsson, J. L. (2010). Rhodothermus profundi sp. nov., a new thermophilic bacterium isolated from a deep-sea hydrothermal vent in the Pacific Ocean. Int J Syst Evol Microbiol 60, 2729-2734.

Mesbah, M., Premachandran, U. \& Whitman, W. B. (1989). Precise measurement of the $\mathrm{G}+\mathrm{C}$ content of deoxyribonucleic acid by high-performance liquid chromatography. Int J Syst Bacteriol 39, 159-167.

Nedashkovskaya, O. I., Suzuki, M., Lee, J.-S., Lee, K. C., Shevchenko, L. S. \& Mikhailov, V. V. (2009). Pseudozobellia thermophila gen. nov., sp. nov., a bacterium of the family Flavobacteriaceae, isolated from the green alga Ulva fenestrata. Int J Syst Evol Microbiol 59, 806-810.

Nielsen, P., Fritze, D. \& Priest, F. G. (1995). Phenetic diversity of alkaliphilic Bacillus strains: proposal for nine new species. Microbiology 141, 1745-1761.

Nunes, O. C., Manaia, C. M., Da Costa, M. S. \& Santos, H. (1995). Compatible solutes in the thermophilic bacteria Rhodothermus marinus and "Thermus thermophilus". Appl Environ Microbiol 61, 2351-2357.
Pires, A. L., Albuquerque, L., Tiago, I., Nobre, M. F., Empadinhas, N., Veríssimo, A. \& da Costa, M. S. (2005). Meiothermus timidus sp. nov., a new slightly thermophilic yellow-pigmented species. FEMS Microbiol Lett 245, 39-45.

Qu, J.-H. \& Yuan, H.-L. (2008). Sediminibacterium salmoneum gen. nov., sp. nov., a member of the phylum Bacteroidetes isolated from sediment of a eutrophic reservoir. Int J Syst Evol Microbiol 58, 2191-2194.

Rainey, F. A., Ward-Rainey, N., Kroppenstedt, R. M. \& Stackebrandt, E. (1996). The genus Nocardiopsis represents a phylogenetically coherent taxon and a distinct actinomycete lineage: proposal of Nocardiopsaceae fam. nov. Int J Syst Bacteriol 46, 1088-1092.

Reasoner, D. J. \& Geldreich, E. E. (1985). A new medium for the enumeration and subculture of bacteria from potable water. Appl Environ Microbiol 49, 1-7.

Silva, Z., Horta, C., da Costa, M. S., Chung, A. P. \& Rainey, F. A. (2000). Polyphasic evidence for the reclassification of Rhodothermus obamensis Sako et al. 1996 as a member of the species Rhodothermus marinus Alfredsson et al. 1988. Int J Syst Evol Microbiol 50, 1457-1461.

Smibert, R. M. \& Krieg, N. R. (1981). General characterization. In Manual of Methods for General Bacteriology, pp. 411-442. Edited by P. Gerhardt, R. G. E. Murray, R. N. Costilow, E. W. Nester, W. A. Wood, N. R. Krieg \& G. B. Phillips. Washington, DC: American Society for Microbiology.

Tamura, K., Dudley, J., Nei, M. \& Kumar, S. (2007). MEGA4: molecular evolutionary genetics analysis (MEGA) software version 4.0. Mol Biol Evol 24, 1596-1599.

Tenreiro, S., Nobre, M. F., Rainey, F. A., Miguel, C. \& da Costa, M. S. (1997). Thermonema rossianum sp. nov., a new thermophilic and slightly halophilic species from saline hot springs in Naples, Italy. Int $J$ Syst Bacteriol 47, 122-126.

Williams, R. A. \& da Costa, M. S. (1992). The genus Thermus and related microorganisms. In The Prokaryotes, 2nd edn, pp. 3745-3753. Edited by A. Balows, H. G. Trüper, M. Dworkin, W. Harder \& K. H. Schleifer. New York: Springer. 